\title{
歯科ろう着に関する研究
}

一埋没材と予備加熱法との相違が適合精度に及ぼす三次元的検討一

\author{
羽田京太郎
}

\section{A Study of Dental Soldering \\ - Three Dimensional Investigation of Influences of the Difference of Soldering \\ Investments and Preheating Procedures on Fitness Accuracy -}

\section{Kyoutarou Hada}

\section{第 1 章 緒 言}

クラウン・ブリッジ学の臨床では使用器材の開発・改 良により，間接法が確立され十分な精度が得られるよう になった. 今日ではブリッジ調整のために, ワンピース キャスト法も多く応用されている. しかし，支台形態に よる制限やユニット数が多い場合では、ワンピースキャ スト法で十分な適合精度が得られず，ろう着法によらな いと適合しない場合が臨床でしばしば経験する.

また異種金属の接合, アタッチメントやテレスコープ システムでの技工操作では，絶対にろう着法に頼らなけ ればならないもの, あるいはろら着法によって製作した 方が好ましいものが多い.

さらに,このろう着操作は使用材料の多さ, 製作工程 の繁雑さ，そして高度の技術を必要とするため，適合精 度に及ぼす影響要因は多くあり，数多くの研究報告1 48) が行われているが、いまだ系統だったろら着法が確立さ れたとはいいがたい.このろう着法の適合精度に影響を 及ぼすと考えられる諸要因は,

1）ブリッジの設定部位1)

2）支台歯の数およびュニット数 ${ }^{1 \sim 3)}$

3）支台歯の形態1)

4） 万う着位置およびろう着部位数 $1,4 \sim 6)$

日本大学大学院歯学研究科歯科臨床系専攻（指導: 五十嵐孝 義教授)

Department of Crown \& Bridge Prosthodontics, Nihon University Graduate School of Dentistry (Director : Prof. Takayoshi Igarashi) 昭和 59 年 1 月 25 日受付
5）ろう着継ぎ手の形状 7 10)

6）ろう着間隙 $5,7,11 \sim 17)$

7) 被ろう着体金属の種類 ${ }^{6,18)}$, ろうの種類 ${ }^{18 ~ 20) ~}$

8）被ろう着体の位置の確定法 ${ }^{21,22)}$

9) 仮着ワックスの流ロウ操作 23 25)

10）被ろう着体の固定法6,12, 21, 23 38)

11）予備加熱法 $2628,39,40$ )

12) フラック $\boldsymbol{X}^{41,42)}$

13） 万う着法 $23,31,43 \sim 48)$

14）冷却法 ${ }^{15,16)}$

15）熱処理法 ${ }^{15)}$

であり，系統的に詳細に解明されていない.

そこで著者はそれらのうちから，ろう着への影響要因 を解明する第 2 段階として，埋没材 $6,12,21,23 \sim 29,32,33,37)$ と

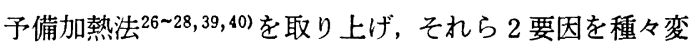
化させ，ろう着した時の支台装置の三次元的変位を計測 し，ろう着精度について検討を加えたので報告する.

\section{第 2 章 材料および方法}

\section{1. 金属原型}

本実験に用いた金属原型（以下金型と略す）は，右側 下顎第 1 大臼歯（以下6门と略す） 久損で，右側下頡第 2 小臼歯（以下5と略す）および右側下顥第 2 大臼歯（以 下7〕略す）を全部鋳造冠支台装置とし，6妾ポンティ ックとする 1 歯欠損の直線型のスリーュニットブリッジ

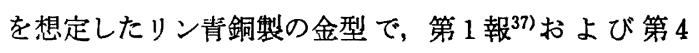
報40)で用いたものと同じである. 
表 1 埋 没材

\begin{tabular}{|c|c|c|c|c|c|}
\hline 試 & 料 & 名 & 略符号 & Batch No. & 混水比 \\
\hline \multicolumn{3}{|c|}{$\begin{array}{l}\text { Deguvest L } \\
\text { (Degussa 社) }\end{array}$} & Deg & 480856 & 0.25 \\
\hline \multicolumn{3}{|c|}{$\begin{array}{l}\text { サクラ埋没材 } \\
\text { (サクラ埋没材研究所) }\end{array}$} & $\mathrm{Sa}$ & - & 0.33 \\
\hline \multicolumn{3}{|c|}{$\begin{array}{c}\mathrm{CM} \text { ソルタリングインベストメント } \\
\text { (Cendres \& Metaux 社) }\end{array}$} & $\mathrm{CM}$ & 20601 & 0.20 \\
\hline \multicolumn{3}{|c|}{$\begin{array}{l}\text { Soldering Investment } \\
\quad \text { (Ransom \& Randolph 社) }\end{array}$} & $\mathrm{R} \& \mathrm{R}$ & 9122 & $0: 25$ \\
\hline
\end{tabular}

\section{2. 試 験 体}

試験体の製作のための， ロウ原型製作，計測基準点 （以下計測点と略す）の設定，埋没・鋳造，ろう着間隙 の設定, 計測点の修正研摩，ろう着前の計測，被万う着 体の位置の確定等すべての術式方法は, 第 1 報 ${ }^{37}$ および 第 4 報40) に従った.

\section{3. 埋 没}

埋没材は，第 2 報24)から，熱膨張率の大きさより以下 の 4 種を選択し使用した.

1) Deguvest L : Degussa 社 (以下 Deg と略す)

2） サクラ埋没材：サクラ埋没材研究所（以下 Sa と 略す)

3） CM ソルダリング・インベストメント : Cendres \& Metaux 社 (以下 $\mathrm{CM}$ と略す)

4) Soldering Investment : Ransom \& Randolph 社 (以下 $R \& R$ と略す)

なお各埋没材の混水比, Batch No. は表 1 に示寸. 埋 没材の使用は第 2 報24)に従って，ハンドミキサー（山浦 社）にて，バイブレーター上で 1 分間 54 回転（スパチ ユラによる毎分 180 回練和に相当）で練和し，試験体の 埋没を行った，埋没ブロックの大きさ，形態は第 1 報 ${ }^{37)}$ ，第 4 報40) と同様，近遠心的に $36 \mathrm{~mm}$, 煩舌的に $20 \mathrm{~mm}$, 高さ $25 \mathrm{~mm}$ の寸法に規定した.

\section{4. 予備加熱法}

予備加熱法は，今回，

(1) ろう着操作の向上

(2) 被万ら着体金属の酸化膜の形成

(3) 埋没ブロックの安定

以上 3 つのことを考慮し，以下の 4 操作に設定した.

1) 操作 1

埋没 1 時間後に仮着ワックスを沸騰水 $(800 \mathrm{ml})$ にて 流口ウ操作を行い，その後 1 時間室温に放置した埋没ブ
表 2 要因と水準

\begin{tabular}{|c|c|c|c|c|}
\hline 要因 水準 & 1 & 2 & 3 & 4 \\
\hline A：埋没材 & & $\mathrm{Sa}$ & $\mathrm{CM}$ & $\mathrm{R} \& \mathrm{R}$ \\
\hline B : 予備 & $(0$ & $(150)$ & $(300)$ & $(600)$ \\
\hline
\end{tabular}

注）A：表 1 を参照のこと

$\mathrm{B}:$ 操作 $1(0)$

操作 $2(150)$

操作 $3(300)$

操作 $4(600)$

ロックをまったく予備加熱を行わず，すぐにろう着操作 に移行したもの (以下操作 1 (0) と略寸).

2) 操作 2

1）の流ロウ操作を行った埋没ブロックを，予備加熱条 件として室温より 15 分で $150^{\circ} \mathrm{C}$ まで上昇させ， 1 時間 15 分係留後乃う着操作に移行したもの（以下操作 2 (150）と略す).

3) 操作 3

1）の流ロウ操作を行った埋没ブロックを，予備加熱条 件として室温より 30 分で $300^{\circ} \mathrm{C}$ まで上昇させ， 1 時間 倸留後万う着操作に移行したもの（以下操作 $3(300)$ と 略す).

4) 操作 4

1)の流ロウ操作を行った埋没ブロックを，予備加熱条 件として室温より 20 分で $200^{\circ} \mathrm{C}$ まで上昇させ 20 分倸 留し, その後 40 分で $600^{\circ} \mathrm{C}$ まで上昇させ 10 分倸留後 万う着操作に移行したもの (以下操作 4 (600) と略す). なお予備加熱には MK-17 型オートマチックファーネ ス（コロナ電気工業社）を用いた。

\section{5. 埋没材と予備加熱法の組合わせ}

本実験では埋没材と予備加熱法の 2 要因を選択し，こ れに各々 4 水淮，計 16 通りの組合わせを設定した（表 2).な掞，試験体数は 1 つの組合わせにつき 5 個と し, 計 80 個とした.

\section{6. 万ら着}

予備加熱なしの試験体はそのまま，予備加熱ありのも のはそれぞれの操作の予備加熱後，バーナー上に置いた ヒートプレート上に埋没ブロックを载せ，埋没ブロック の冷却の恐れがないよう考慮しつつ，ブローパイプの火 炎で加熱して日常臨床で行う方法 ${ }^{40)}$ にてろう着を行っ た. なお使用フラックス，ろう，ろう着およびろう着後 の泠却方法等はすべて第 4 報40) に従った. 


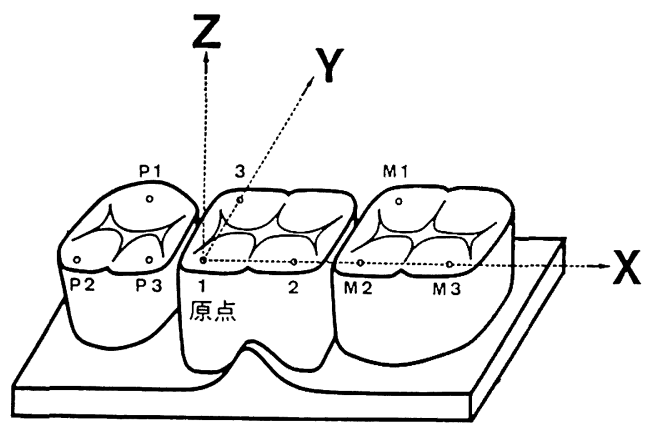

図 1 計測方法

\section{第 3 章 計測方法}

\section{1. 計測方法}

ろう着により，すでに動いてしまった支台装置は，原 型支台歯へどのように戻すかが問題となる．特に適合の 悪いものでは，一方を合わせようとすると，他方が浮き 上がるといらシーソー現象を生じ，合わせ方により毎回 異なった評価をしてしまう危除性がつきまとう。そこ で，動いてしまった支台装置を原型支台歯へ戻すことは 不可能であり，かつ避けなければならないと考え，第 4 報40)に報告したと㧍り Nicholls ${ }^{49 \sim 51)}$ の方法を参考に計 測方法を確立した．すなわち図1に示すように，まずポ ンティック上の計測点 $1 \cdot 2 \cdot 3$ の 3 点より計測基準平面 を設定し, 計測点 $1 \cdot 2$ でX軸, 計測点 $1 \cdot 3$ で $\mathrm{Y}$ 軸, 計 測点 1 で $\mathrm{X}=0, \mathrm{Y}=0, Z=0$ の原点を決定し, 三次元座 標軸を設定した. そして, 5 の計測点 $\mathrm{P} 1 \cdot \mathrm{P} 2 \cdot \mathrm{P} 3,7\rceil の$ 計測点 $\mathrm{M} 1 \cdot \mathrm{M} 2 \cdot \mathrm{M} 3$ ，それぞれ 3 つの計測点のろう着 前後の三次元座標値の変化より, ろう着により製作した ブリッジを金型に戻すことなく，両支台装置のポンティ ックに対する相対的な三次元的変位を計測した.

計測器械は第 4 報 ${ }^{40}$ 同様, 三次元デジタル座標測定機 XYZAX M400-B (東京精密社) と NOVA 4C 型ミニコ ンピュータ（日本データゼネラル社）を用いた.

なお，計測精度は第 4 報40)のとおり各座標共, 平均值 のばらつきである管理限界の幅で $0.010 \mathrm{~mm}$ 以下，標準 偏差値で $0.006 \mathrm{~mm}$ 以下であった.

\section{2. 計測項目}

ろう着による支台装置の三次元的変位について, Nicholls ${ }^{49 \sim 51)}$ は直線的な移動 3 成分, 回転によるねじれ 3 成分, 計 6 つの構成成分より表している. 寸なわち, 3 つの計測点の内の 1 点を代表点とし，その 1 点がろう
28 巻 3 号 (1984)

着前の元の位置まで戻すのに必要な $\mathrm{X} \cdot \mathrm{Y} \cdot \mathrm{Z}$ 各座標に おける距離を算出し，直線的な移動量として表し，また 元の位置に戻ったその 1 点を原点（回転中心）として， 残りの $2 つ$ 計測点を $\mathrm{X} \cdot \mathrm{Y} \cdot \mathrm{Z}$ 軸の回転により元の位 置に戻し，その時に必要な軸の回転角度を算出し，ねじ れとして表している.

今回, この Nicholls ${ }^{49 \sim 51)}$ の支台装置の三次元的変位 の表し方に従い, 以下の計測項目を設定した.

\section{1) 移動}

5|・7|のそれぞれの 3 つの計測点をろう着前後におい て，ポンティック上の計測点 $1 \cdot 2 \cdot 3$ に対し各計測点の $\mathrm{X} \cdot \mathrm{Y} \cdot \mathrm{Z}$ 座標值を計測した. 今回は5 5 では計測点 $\mathrm{P} 3$, 7|では計測点 M2 を各支台装置の代表計測点として,ろ う着後の $\mathrm{X} \cdot \mathrm{Y} \cdot \mathrm{Z}$ 各座標值とろう着前の $\mathrm{X} \cdot \mathrm{Y} \cdot \mathrm{Z}$ 各 座標値との差により, 直線的な移動量として以下の 3 方 向に分け算出した.

(1) $\Delta \mathrm{X}$ (近遠心的移動量)

(2) $\Delta \mathrm{Y}$ (煩舌的移動量)

(3) $\Delta Z$ (垂直的移動量)

2) ねじれ

前記の移動により， 万う着前の位置に戻したらの計測 点 $\mathrm{P} 3$ と7|の計測点 $\mathrm{M} 2$ を原点 (回転中心) として, 残 りの 2 つの計測点を $\mathrm{X} \cdot \mathrm{Y} \cdot \mathrm{Z}$ 各座標軸の回転により元 の位置に戻し，その時に必要な回転角度を以下に示すよ うな权じれとして算出した。

(1) $\Delta \theta \mathrm{X}(\mathrm{X}$ 軸の回転角度)

(2) $\Delta \theta \mathrm{Y}$ ( $\mathrm{Y}$ 軸の回転角度)

(3) $\Delta \theta Z$ ( $Z$ 軸の回転角度)

回転角度の算出方法は, 軸の回転に伴う計測点の新し い三次元座標值を行列より交換し求め，たとえば5枕 いて，3つの計測点が以下のような座標值とすると（図 $2)$,

$\mathrm{P} 1\left(\mathrm{x}_{1}, \mathrm{y}_{1}, \mathrm{z}_{1}\right)$

$\mathrm{P} 2\left(\mathrm{x}_{2}, \mathrm{y}_{2}, \mathrm{z}_{2}\right)$

$\mathrm{P} 3\left(\mathrm{x}_{3}, \mathrm{y}_{3}, \mathrm{z}_{3}\right)$

まず, 計測点 P3 をポンティック上の原点に（図 2-b 参照）移動させ，それを回転中心とし，計測点 P2 がX 軸上に（図 2-c 参照)，かつ計測点 P1 が計測基準 (XY) 平面上に (図 2-d 参照) 移動させるのに必要な X·Y • $Z$ 各座標軸の回転角度を，ろう着前およびろう着後で以 下の式より算出した.

$$
\begin{aligned}
& \theta Z=-\arctan \frac{y_{2}-y_{3}}{x_{2}-x_{3}} \\
& \theta Y=-\arctan \frac{z_{2}-z_{3}}{\left(x_{2}-x_{3}\right) \operatorname{Cos} \theta Z-\left(y_{2}-y_{3}\right) \operatorname{Sin} \theta Z}
\end{aligned}
$$




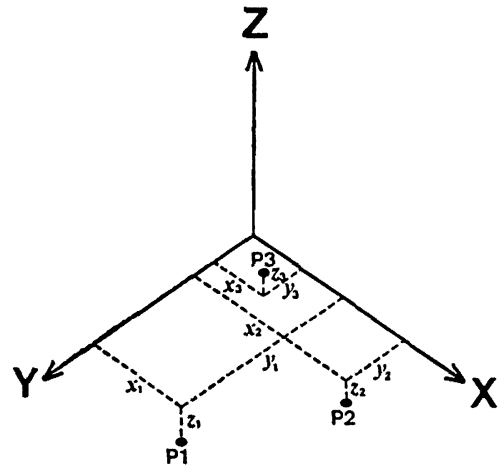

a ポンティック上の原点に対する P1 P2 ・ P3 の三次元座標值

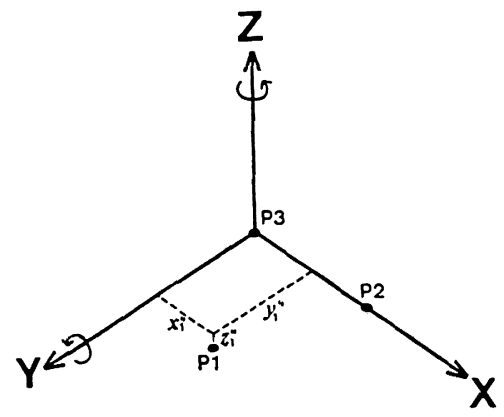

c Z 軸およびY軸の回転により計測点 $\mathrm{P} 2$ を $\mathrm{X}$ 軸上に移動した状態

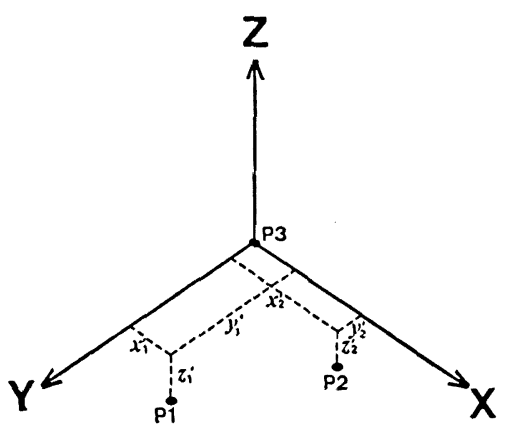

b 計測点 $\mathrm{P} 3$ をポンティック上の原点に移動し た状態

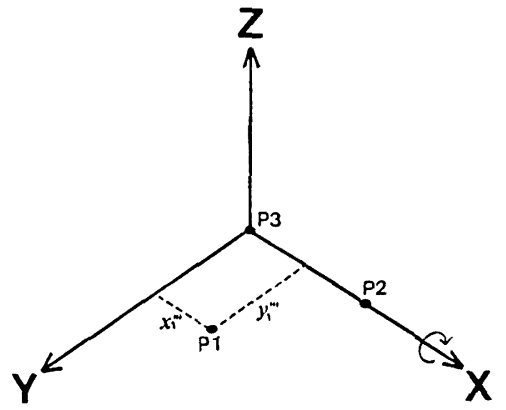

$\mathrm{d} \quad \mathrm{X}$ 軸の回転により計測点 $\mathrm{P} 1$ 索計測基準 (XY) 平面上に移動した状態

図 2 座標軸の回転角度の算出方法

$$
\theta \mathrm{X}=-\arctan \frac{-\left(\mathrm{z}_{1}-\mathrm{z}_{3}\right) \operatorname{Cos} \theta \mathrm{Y}}{\frac{-\left(\mathrm{x}_{1}-\mathrm{x}_{3}\right) \operatorname{Cos} \theta \mathrm{Z} \operatorname{Sin} \mathrm{Y} \theta}{\left(\mathrm{y}_{1}-\mathrm{y}_{3}\right) \operatorname{Cos} \theta \mathrm{C}+\left(\mathrm{y}_{1}-\mathrm{x}_{3}\right) \operatorname{Sin} \theta \mathrm{Z}}}
$$

そしてろう着前とろう着後の各座標軸の回転角度の差よ り，ねじれを $\Delta \theta \mathrm{X}$ ( $\mathrm{X}$ 軸の回転角度), $\Delta \theta \mathrm{Y}$ ( $\mathrm{Y}$ 軸の回転 角度) および $\Delta \theta Z$ ( $Z$ 軸の回転角度) に分け算出した.

\section{第 4 章 成樍}

\section{1. 移 動}

ろう着による両支台装置の $\Delta \mathrm{X}$ (近遠心的移動量), $\Delta \mathrm{Y}$ (煩舌的移動量)， $\Delta Z$ (垂直的移動量) の平均値と標準偏 差值を表 3 に, 平均値と平均値の $95 \%$ 信頼区間を図 3〜8 に示す.

\section{2. ねじれ}

ろう着による両支台装置のねじれを $\Delta \theta \mathrm{X}$ ( $\mathrm{X}$ 軸の回転 角度), $\Delta \theta \mathrm{Y}$ ( $\mathrm{Y}$ 軸の回転角度), $\Delta \theta Z$ ( $\mathrm{Z}$ 軸の回転角度)
として算出し，得られた回転角度の平均値と標準偏差值 を表 4 に，平均值と平均値の $95 \%$ 信頼区間を図 9〜14 に示す.

\section{第 5 章 総括および検討}

本研究はろう着法の適合精度に影響を及ぼすと考えら れる要因のうち, 特定の要因を変化させたり, 要因の組 合わせを変化させ，どの要因が適合精度に大きく影響す るのかを明らかにし，どのような器材と技工術式を用い れば，正確なろう着が可能かを調べる目的で行ったもの である。

今回はその要因のうちから埋没材と予備加熱法の 2 要 因を取り上げ，それら 2 要因を変化させ実験を行った.

\section{1. 要因選択の基準}

1）埋没材について

ろう着体の位置を確定した被ろう着体は，なんらかの 
表 3 移 動 量

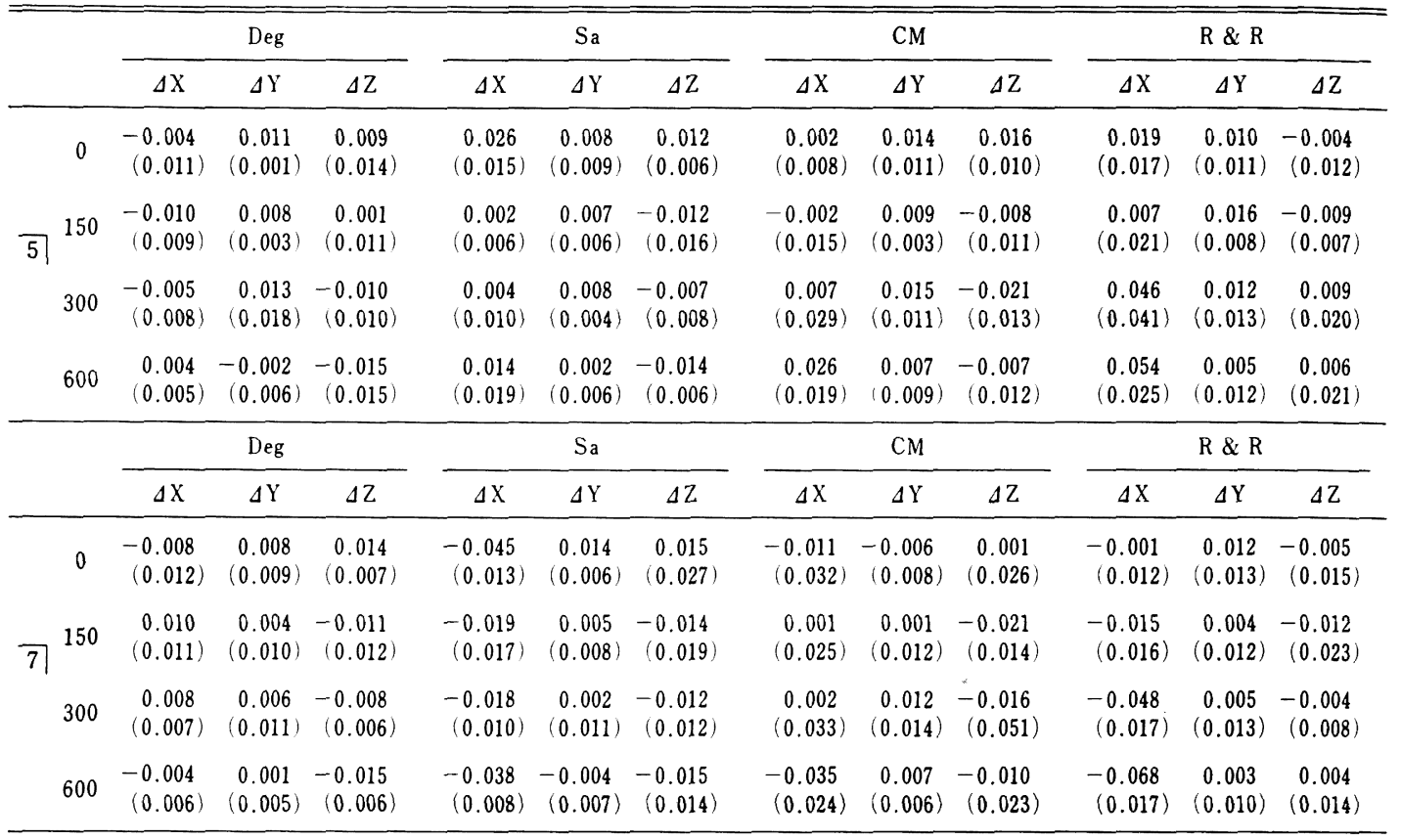

注） $\Delta \mathrm{X}$ (近遠心的移動量)：正の値は遠心側へ，負の値は近心側へ移動したことを表す

$\Delta \mathrm{Y}$ (頼舌的移動量)：正の值は煩側へ，負の值は舌側へ移動したことを表す

$\Delta \mathrm{Z}$ (垂直的移動量)：正の值は咬合面側へ，負の值は菌頸部側へ移動したことを表す

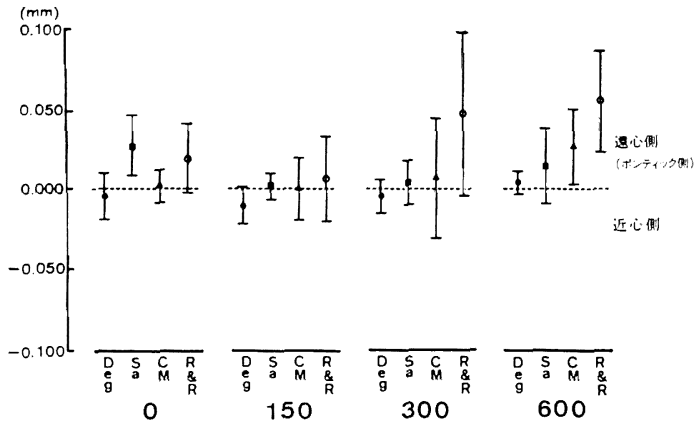

注）正の值は遠心側（ポンティック側）へ，負の值は近心側 へ移動したことを表す

图 $3 \quad \overline{5} \mid \cdot \Delta \mathrm{X}$ (近遠心的移㙑㱖)

方法によって動かないように固定しなければならない. 固定法として湯田 ${ }^{21)}$ は,

(1) 埋没材を使用して固定する埋没材固定法

(2) 連結用ワイヤーを用いて被ろう着体を電気溶接に よって仮固定する電気溶接固定法

(3) その他の方法

以上の 3 つに大く分類している.

埋没材固定法には, 埋没材たけで固定する方

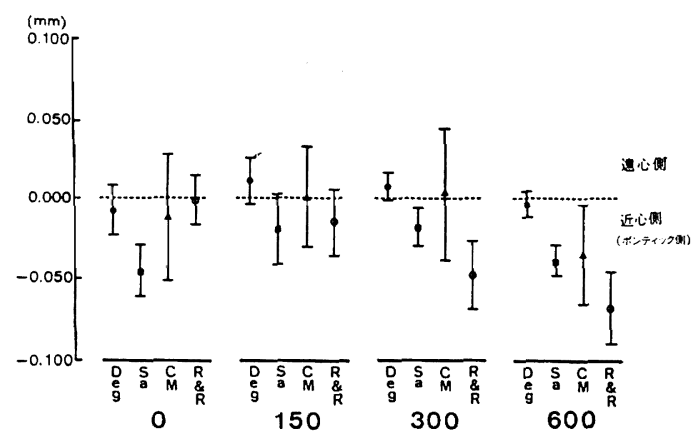

注）正の値は遠心側へ，負の值は近心側（ポンティック側） へ移動したことを表す

図 $4 \quad \overline{7} \mid \cdot \Delta \mathrm{X}$ (近遠心的移動量)

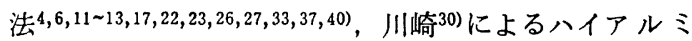
十補強材を埋入し埋没材を小さく分割する方法, 小柳 津 $^{311}$ による自家製ろう着用金属固定装置を応用する方 法, 太田ら ${ }^{381}$ による陶材焼成用金属トレーを応用する方 法，妹尾ら ${ }^{36)}$ による特殊セラミック製のソルダリングス タンドを応用する方法等が報告されている，しかし今回 は特殊な器具・装置を使用せず簡便に行え, 一般臨床は いうまでもなく学生実習にも幅広く応用され，かつ埋没 


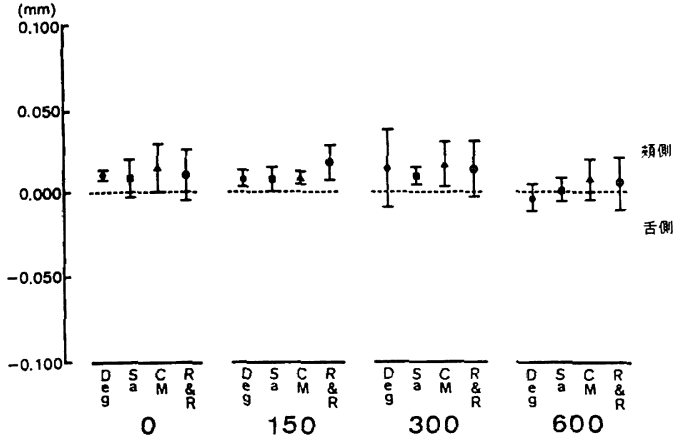

注）正の值は煩側へ，負の值は舌側へ移動したことを表す

図 $5 \quad \overline{5} \mid \cdot \Delta \mathrm{Y}$ (煩舌的移動量)

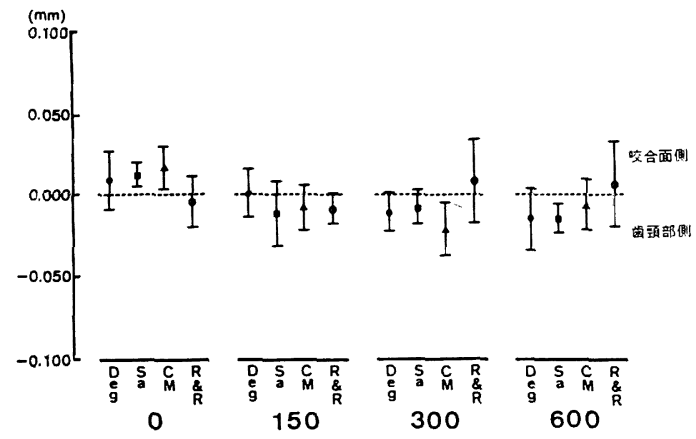

注）正の值は咬合面側へ，負の值は歯䫫部側へ移動したこと を表才

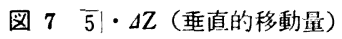

材の持つ性質が直接表れると考えられる方法のうち, 確 定法には咬合面を金属補強棒（直径 $3 \mathrm{~mm}$ ) によりステ イッキーワックス（Model Cement·Ash 社）にて位置 決めし，その後埋没材だけで固定する方法を取り上げた.

埋没材はろう着材として母体をなすものであり，古く から多くの研究報告6,12,21,23 29,32,33,37) がなされてきた. そのほとんどは試作埋没材 ${ }^{23,26,27,32,33)}$ についてであり， 結合材, 耐火材, 添加物の配合・調整により研究者の考 え方に合致した埋没材を製作することを目的としたもの である. しかし，一般臨床ではその都度埋没材を配合 · 調整し使用することは不可能で，すぐに使用できる市販 ろら着専用埋没材を使用しているのが現状である.この ことは, 1976 年湯田 ${ }^{28)}$ が行った都内技工士 100 名のアン ケート調查でも明らかで，その使用率は市販ろう着専用 埋没材がほとんどで，鋳造用埋没材での代用，あるいは 自家製埋没材の使用は 1 割にすぎない.

ろう着用埋没材の理工学的性質のうちで，ろう着法の 適合精度に影響を及ぼすと考えられる硬化膨張について

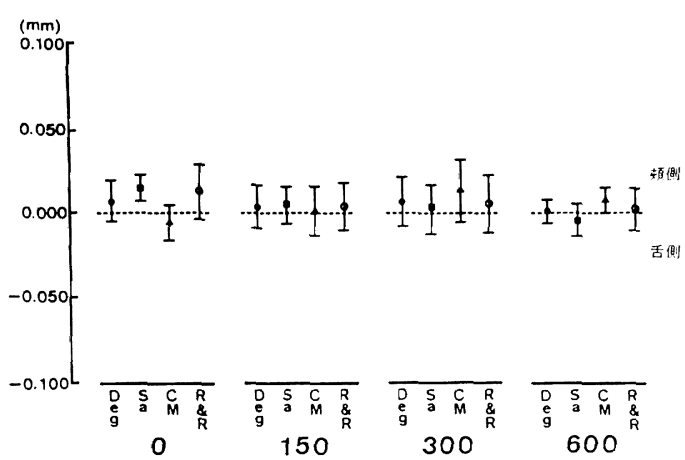

注) 図 5 下注) 参照

图 $6 \quad \overline{7} \mid \cdot \Delta \mathrm{Y}$ (煩舌的移動量)

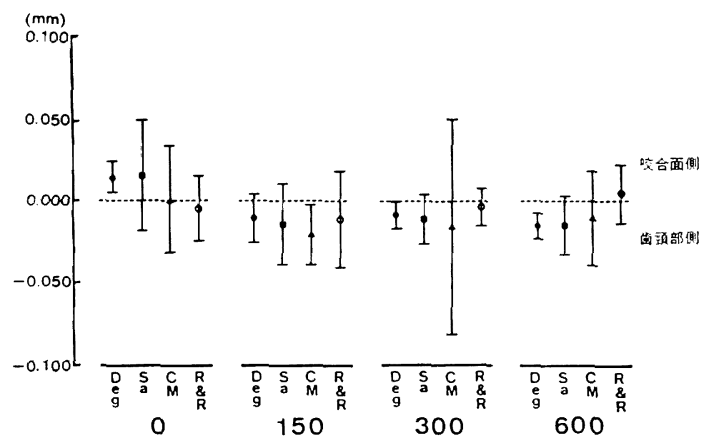

注) 図 7 下注) 参照

图 $8 \quad \overline{7} \mid \cdot \Delta Z$ (垂直的移動量)

は，膨張率が小さく，0に近いものが望ましい23 28,32) との研究者の見解が一致しているが，加熱膨張について は，その見解が一致していない.すなわち，

(1) 熱膨張曲線が被ろう着体金属のそれに近いも $の^{23,27)}$

(2) 加熱途中で伸び縮みが急激に起こらず，ろう着温 度付近で熱膨張曲線のなだらかなもの ${ }^{26)}$

(3) 加熱により寸法変化を示さず，熱膨張率が 0 か 0 に等しいもの ${ }^{28,32)}$

以上 3 つの見解に分かれている.

そこで第 2 報 ${ }^{24)}$ のよおり，わが国で入手可能な 6 種市 販万弓着専用埋没材の理工学的性質について調べたが,

(1)と(3)の特性を示すものは無く，すべて(2)の特性を示す ものであった．そこで今回は(2)の特性を示す市販ろう着 専用埋没材のうちから，熱膨張率の大小がろら着精度に どのように影響するかを調べるため，熱膨張率の大きさ より Deg, Sa，CM， R \& R の 4 種の埋没材を選び使用 した. 使用ろう（16 K 万う・徳力社）の融点 $\left(760^{\circ} \mathrm{C}\right)$ 
表 4 ねじれ（軸の回転角度）

\begin{tabular}{|c|c|c|c|c|c|c|c|c|c|c|c|c|c|}
\hline & & \multicolumn{3}{|c|}{ Deg } & \multicolumn{3}{|c|}{$\mathrm{Sa}$} & \multicolumn{3}{|c|}{$\mathrm{CM}$} & \multicolumn{3}{|c|}{$\mathrm{R} \& \mathrm{R}$} \\
\hline & & $\Delta \theta \mathrm{X}$ & $\Delta \theta \mathrm{Y}$ & $\Delta \theta \mathrm{Z}$ & $\Delta \theta \mathrm{X}$ & $\Delta \theta \mathrm{Y}$ & $\Delta \theta \mathrm{Z}$ & $\Delta \theta \mathrm{X}$ & $\Delta \theta \mathrm{Y}$ & $\Delta \theta \mathrm{Z}$ & $\Delta \theta \mathrm{X}$ & $\Delta \theta \mathrm{Y}$ & $\Delta \theta \mathrm{Z}$ \\
\hline \multirow{6}{*}{5} & 0 & $\begin{array}{c}-0.18 \\
(0.18)\end{array}$ & $\begin{array}{c}0.15 \\
(0.16)\end{array}$ & $\begin{array}{c}-0.17 \\
(0.09)\end{array}$ & $\begin{array}{c}-0.36 \\
(0.15)\end{array}$ & $\begin{array}{c}0.25 \\
(0.19)\end{array}$ & $\begin{array}{c}-0.10 \\
(0.07)\end{array}$ & $\begin{array}{c}-0.22 \\
(0.10)\end{array}$ & $\begin{array}{c}0.02 \\
(0.26)\end{array}$ & $\begin{array}{c}-0.05 \\
(0.09)\end{array}$ & $\begin{array}{c}0.06 \\
(0.25)\end{array}$ & $\begin{array}{c}0.09 \\
(0.46)\end{array}$ & $\begin{array}{c}-0.07 \\
(0.17)\end{array}$ \\
\hline & 150 & $\begin{array}{c}-0.11 \\
(0.13)\end{array}$ & $\begin{array}{c}0.09 \\
(0.13)\end{array}$ & $\begin{array}{c}-0.06 \\
(0.05)\end{array}$ & $\begin{array}{c}-0.17 \\
(0.07)\end{array}$ & $\begin{array}{c}0.15 \\
(0.06)\end{array}$ & $\begin{array}{c}-0.10 \\
(0.07)\end{array}$ & $\begin{array}{c}-0.24 \\
(0.14)\end{array}$ & $\begin{array}{c}0.16 \\
(0.11)\end{array}$ & $\begin{array}{c}-0.13 \\
(0.05)\end{array}$ & $\begin{array}{c}-0.16 \\
(0.10)\end{array}$ & $\begin{array}{c}0.16 \\
(0.13)\end{array}$ & $\begin{array}{c}-0.13 \\
(0.10)\end{array}$ \\
\hline & 300 & $\begin{array}{c}-0.08 \\
(0.09)\end{array}$ & $\begin{array}{c}0.03 \\
(0.11)\end{array}$ & $\begin{array}{c}-0.10 \\
(0.05)\end{array}$ & $\begin{array}{r}-0.25 \\
(0.17)\end{array}$ & $\begin{array}{c}0.25 \\
(0.15)\end{array}$ & $\begin{array}{c}-0.02 \\
(0.09)\end{array}$ & $\begin{array}{c}-0.11 \\
(0.43)\end{array}$ & $\begin{array}{c}0.23 \\
(0.21)\end{array}$ & $\begin{array}{c}0.15 \\
(0.24)\end{array}$ & $\begin{array}{c}-0.20 \\
(0.42)\end{array}$ & $\begin{array}{c}0.04 \\
(0.36)\end{array}$ & $\begin{array}{c}-0.20 \\
(0.10)\end{array}$ \\
\hline & 600 & $\begin{array}{c}0.09 \\
(0.20)\end{array}$ & $\begin{array}{c}-0.09 \\
(0.16\}\end{array}$ & $\begin{array}{c}0.00 \\
(0.08)\end{array}$ & $\begin{array}{c}0.01 \\
(0.21)\end{array}$ & $\begin{array}{c}0.01 \\
(0.24)\end{array}$ & $\begin{array}{c}-0.04 \\
(0.12)\end{array}$ & $\begin{array}{c}-0.11 \\
(0.22)\end{array}$ & $\begin{array}{c}0.04 \\
(0.24)\end{array}$ & $\begin{array}{c}0.00 \\
(0.11)\end{array}$ & $\begin{array}{c}0.07 \\
(0.16)\end{array}$ & $\begin{array}{c}-0.17 \\
(0.16)\end{array}$ & $\begin{array}{c}-0.15 \\
(0.12)\end{array}$ \\
\hline & & \multicolumn{3}{|c|}{ Deg } & \multicolumn{3}{|c|}{$\mathrm{Sa}$} & \multicolumn{3}{|c|}{$\mathrm{CM}$} & \multicolumn{3}{|c|}{$R \& R$} \\
\hline & & $\Delta \theta \mathrm{X}$ & $\Delta \theta \mathrm{Y}$ & $\Delta \theta \mathrm{Z}$ & $\Delta \theta \mathrm{X}$ & $\Delta \theta \mathrm{Y}$ & $\Delta \theta \mathrm{Z}$ & $\Delta \theta \mathrm{X}$ & $\Delta \theta \mathrm{Y}$ & $\Delta \theta Z$ & $\Delta \theta \mathrm{X}$ & $\Delta \theta \mathrm{Y}$ & $\Delta \theta \mathrm{Z}$ \\
\hline \multirow{4}{*}{77} & 0 & $\begin{array}{c}-0.11 \\
(0.14)\end{array}$ & $\begin{array}{c}0.03 \\
(0.07)\end{array}$ & $\begin{array}{c}0.12 \\
(0.06)\end{array}$ & $\begin{array}{c}-0.25 \\
(0.15)\end{array}$ & $\begin{array}{c}-0.15 \\
(0.13)\end{array}$ & $\begin{array}{c}0.01 \\
(0.20)\end{array}$ & $\begin{array}{c}-0.10 \\
(0.14)\end{array}$ & $\begin{array}{c}-0.10 \\
(0.08)\end{array}$ & $\begin{array}{c}0.12 \\
(0.14)\end{array}$ & $\begin{array}{c}0.02 \\
(0.17)\end{array}$ & $\begin{array}{c}0.32 \\
(0.24)\end{array}$ & $\begin{array}{c}0.04 \\
(0.09)\end{array}$ \\
\hline & 150 & $\begin{array}{c}0.02 \\
(0.14)\end{array}$ & $\begin{array}{r}-0.14 \\
(0.15)\end{array}$ & $\begin{array}{c}0.10 \\
(0.10)\end{array}$ & $\begin{array}{r}-0.04 \\
(0.21)\end{array}$ & $\begin{array}{c}-0.29 \\
(0.13)\end{array}$ & $\begin{array}{c}0.15 \\
(0.08)\end{array}$ & $\begin{array}{r}-0.05 \\
(0.12)\end{array}$ & $\begin{array}{c}-0.14 \\
(0.16)\end{array}$ & $\begin{array}{c}0.13 \\
(0.14)\end{array}$ & $\begin{array}{c}0.02 \\
(0.12)\end{array}$ & $\begin{array}{r}-0.20 \\
(0.26)\end{array}$ & $\begin{array}{c}0.07 \\
(0.09)\end{array}$ \\
\hline & 300 & $\begin{array}{r}-0.06 \\
(0.09)\end{array}$ & $\begin{array}{r}-0.12 \\
(0.06)\end{array}$ & $\begin{array}{l}0.06 \\
(0.10)\end{array}$ & $\begin{array}{c}-0.02 \\
(0.14)\end{array}$ & $\begin{array}{c}-0.21 \\
(0.04)\end{array}$ & $\begin{array}{c}0.05 \\
(0.12)\end{array}$ & $\begin{array}{c}0.05 \\
(0.50)\end{array}$ & $\begin{array}{c}-0.08 \\
(0.32)\end{array}$ & $\begin{array}{c}0.18 \\
(0.09)\end{array}$ & $\begin{array}{c}0.04 \\
(0.29)\end{array}$ & $\begin{array}{c}-0.03 \\
(0.16)\end{array}$ & $\begin{array}{c}0.02 \\
(0.23)\end{array}$ \\
\hline & 600 & $\begin{array}{c}0.10 \\
(0.10)\end{array}$ & $\begin{array}{c}0.05 \\
(0.03)\end{array}$ & $\begin{array}{c}0.03 \\
(0.07)\end{array}$ & $\begin{array}{c}-0.09 \\
(0.15)\end{array}$ & $\begin{array}{c}-0.04 \\
(0.12)\end{array}$ & $\begin{array}{c}0.02 \\
(0.06)\end{array}$ & $\begin{array}{c}-0.19 \\
(0.36)\end{array}$ & $\begin{array}{c}0.04 \\
(0.28)\end{array}$ & $\begin{array}{c}0.00 \\
(0.12)\end{array}$ & $\begin{array}{c}-0.43 \\
(0.30)\end{array}$ & $\begin{array}{c}0.17 \\
(0.15)\end{array}$ & $\begin{array}{c}0.08 \\
(0.08)\end{array}$ \\
\hline
\end{tabular}

注） $\Delta \theta \mathrm{X}: \mathrm{X}$ 軸の回転角度 $\Delta \theta \mathrm{Y}: \mathrm{Y}$ 軸の回転角度 $\Delta \theta \mathrm{Z}: \mathrm{Z}$ 軸の回転角度 正の值は反時計回り，負の值は時計回りに回転したことを表す

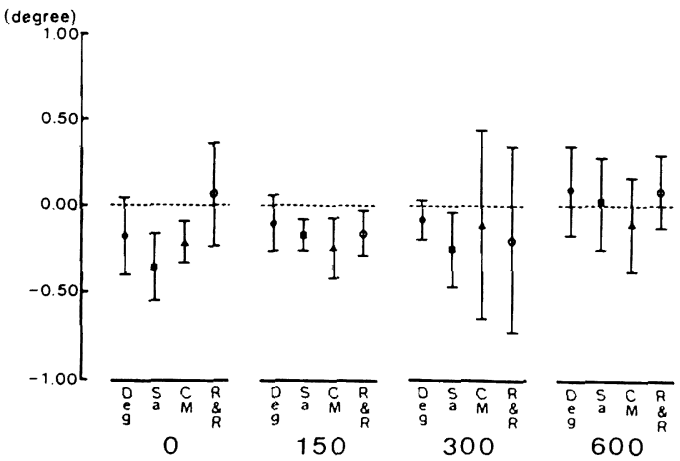

注）正の值は反時計回り，負の值は時計回りに回転したこと を表市

图 $9 \overline{5} \mid \cdot \Delta \theta \mathrm{X}(\mathrm{X}$ 軸の回転角度）

より予想されるろう着温度 $760 \sim 850^{\circ} \mathrm{C}$ の間におけるそ れぞれの熱膨張率は, Deg が $0.80 〜 0.83 \%$, Sa が 0. 55〜0.57\%, CM が0.39〜0.44\%, R \& R が 0.20〜 $0.22 \%$ である. 各々の埋没材が約 $0.2 \%$ の差をもつ（図 15). なお第 2 報で得られた 4 種埋没材の硬化膨張率 は, Deg が $0.08 \%$, Sa が $0.16 \%$, CM が $0.02 \%$ で熱膨 張率に比べ著しく小さかった.

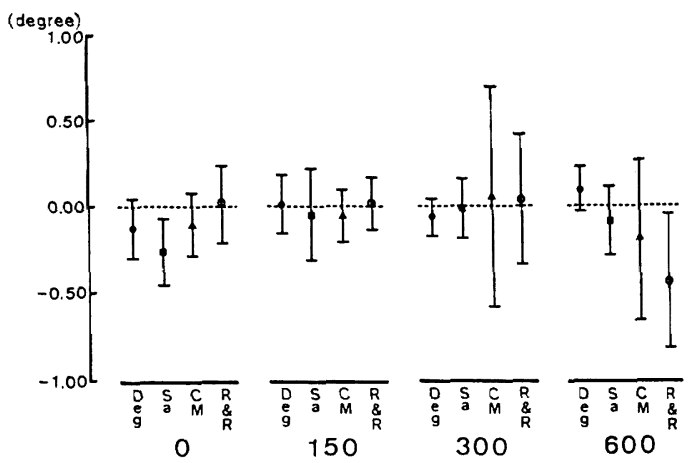

注) 図 9 下注) 参照

図 $10 \quad \overline{7} \mid \cdot \Delta \theta \mathrm{X}$ (X軸の回転角度）

2）予備加熱法について

被ろら着体の固定に埋没材が用いられると，予備加熱 操作は以下の目的により，ろう着操作の中で必要不可欠 なものといわれてきた.

成書 ${ }^{5,14 \sim 16)}$ によると, 埋没した被ろう着体の予備加 熱 の目的としては,

(1) 埋没材から水分を取り除くこと. 水分を多く含ん でいる埋没材をそのままろう着温度まで加熱する 


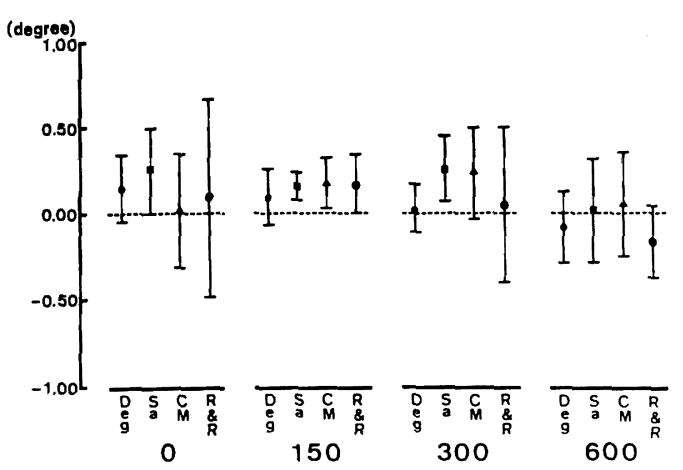

注) 図 9 下注) 参照

図 $11 \overline{5} \mid \cdot \Delta \theta \mathrm{Y}$ (Y軸の回転角度)

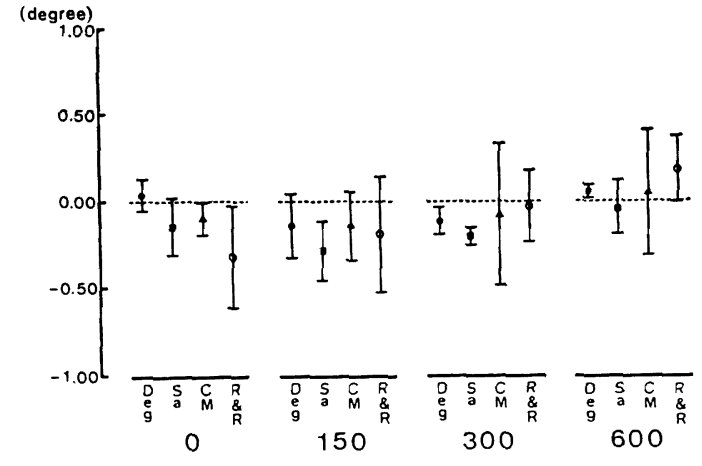

注) 図 9 下注) 参照

图 $12 \overline{7} \mid \cdot \Delta \theta \mathrm{Y}$ ( $\mathrm{Y}$ 軸の回転角度 $)$

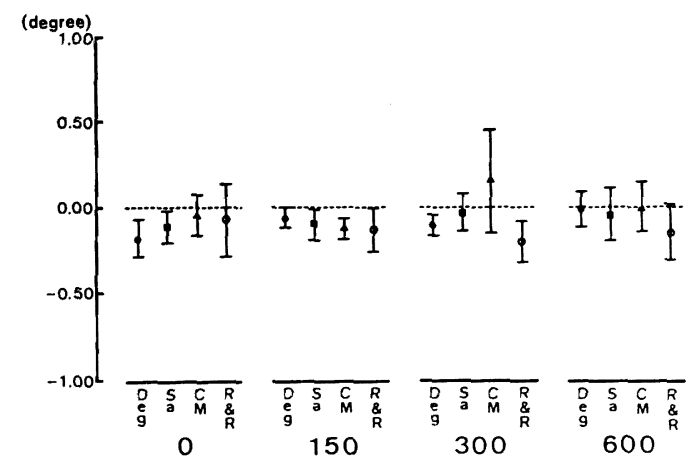

注）図 9 下注）参照

図 $13 \overline{5} \mid \cdot \Delta \theta Z$ （Z 軸の回転角度）

と，ヒビ割れ，破損し位置が狂うので，これを予 防する

(2) 埋没材および金属を，ろうが溶触し流れるよう， ろう着温度まで上梨させるため

(3) 埋没材に熱膨張を起こさせ，金属の加熱時の膨張 に接近させるため

などがあげられている.

しかし，予備加熱操作に関する研究 ${ }^{26 ~ 28,39,40)} の$ 多く は, 昇温速度, 係留時間などの温度管理状態をくわしく 記載していない，予備加熱操作はろう着操作のうちでも このように比較的軽視されている. そのため一般臨床で もさまざまな方法がとられているのが現状である. 最近 では予備加熱を特に必要としないとメーカーが表示して いる埋没材も市販されているので，これらの点を明らか にするため, 予備加熱操作について水準を以下の 4 操作 に設定した.

(1) 操作 1(0)

もし予備加熱しなくても良いとなると，適合精度化影

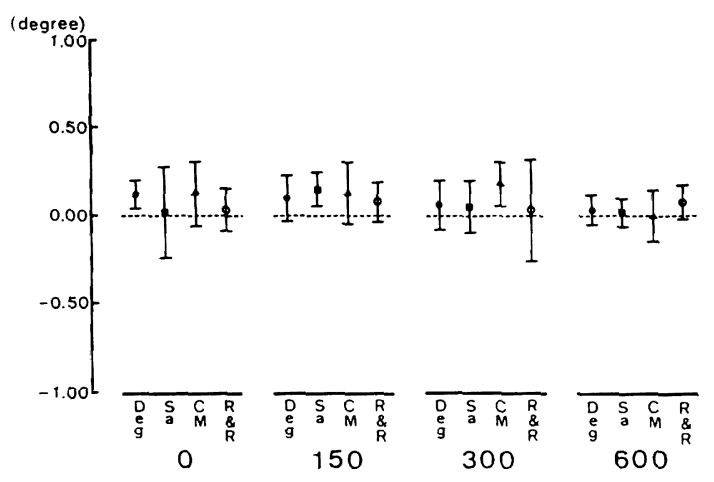

注) 図 9 下注) 参照

図 $14 \overline{7} \mid \cdot \Delta \theta Z$ ( $Z$ 軸の回転角度)

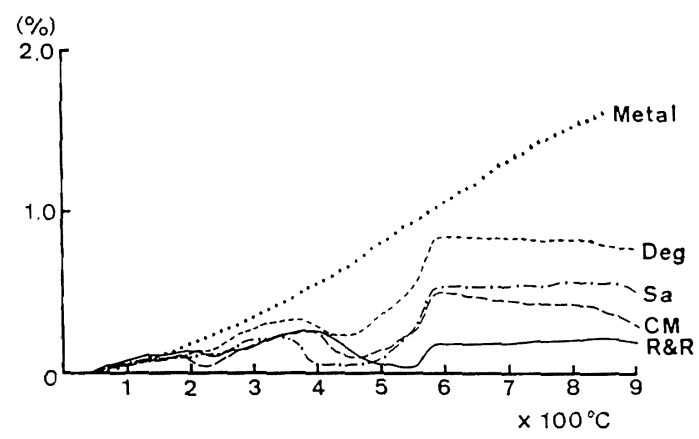

図 15 試験体金属と埋没材の加熱膨張曲線

響を及ぼすと考えられる要因から予備加熱の要因を除去 できる.このことは技工時間の短縮，埋没ブロックの温 度管理, 酸化膜形成, リングファーネスを特にろう着の ために温度管理しなければならないという問題もなくな るので，一般臨床に益するところ，はなはだ大である.

CM は特に予備加熱を必要としないとメーカー表示し 
ている．しかし，第 2 報24)でも報告したように，この埋 没材も他の埋没材に比べ大きく異なる点はなく，熱膨張 曲線も他の 3 種類の埋没材とほぼ同じ曲線を示した（図 15). それなのになぜこの埋没材だけが成書で必要不可 欠とされている予備加熱を必要としないとしているの か, この点を明らかにするとともに, 他の 3 種類の埋没 材でも予備加熱は除くことができないのかを検討するた め，操作 $1(0)$ を設定した。

(2) 操作 2(150)

保母 ${ }^{14)}$ 後万う着について，陶材焼付用金属は酸化し にくい特性を持っているが, Type III 金合金は予備加熱 の間に著しく酸化し，ろう着操作を不可能にすることが あると述べている。 そこで彼は，予備加熱温度は埋没材 中の水分を蒸発させるための最低温度の $150^{\circ} \mathrm{C}$ のみで 十分であるとしている.

大野 ${ }^{52)}$ は歯科用金属の酸化膜の形成について，その大 部分は $\mathrm{Cu}$ によるもので, $\mathrm{Cu}$ の浱度に比例し，かつ温度 の上昇に伴い增加すると報告している．今回使用した金 属（KP エース 200S ナイスショット・徳力社）の $\mathrm{Cu}$ 泣 $24.5 \%$ と金属の $1 / 4$ を占めるため, 保母 ${ }^{14)}$ の報告を基 に酸化膜の形成を少なく，かつ埋没材の水分を蒸発させ る最低温度として，操作 2 (150) を設定した.

(3) 操作 $3(300)$

湯田 ${ }^{28)}$ は埋没材から水分を取り除くことが予備加熱の 主目的として，常温時㧍よび加熱時における埋没材の重 量を測定し，その減量を水分の蒸発によるものと想定し 実験を行っている，その結果， $300 \sim 400^{\circ} \mathrm{C}$ 付近で水分 は完全に除去され乾燥状態を呈したと報告している.

さらに湯田 ${ }^{399}$ は，ろら着操作でどうしても避けること のできない金属表面の酸化は，万らのぬれ性や流動性を 低下させるばかりでなく，万う着部に多孔性欠損を生じ させ機械的強度を弱くする最も有害な要因であるとし， 大気中に扔ける歯科用合金（金合金，金銀パラジウム合 金, $\mathrm{Co}-\mathrm{Cr}$ 合金, $\mathrm{Ni}-\mathrm{Cr}$ 合金）の酸化膜の温度上昇に伴 亏経時的生成状態を，肉眼的および顕微鏡的観察を行っ ている.その結果，どの種の合金の場合も $300^{\circ} \mathrm{C}$ 以下 ではろう着に直接影響を及ぼすと思われるような酸化膜 は形成されないが, $300^{\circ} \mathrm{C}$ 以上になると温度の上昇に伴 い急速に形成されると報告している，以上のことより酸 化膜の形成を少なく，かつ埋没材中の水分を蒸発させる 最高温度として，操作 3 （300）を設定した.

(4) 操作 4 (600)

野本ら ${ }^{27)}$ は，火炎ろう着の場合，ろう着部付近は急激 に加熱されるため, 予備加熱温度が低いと埋没ブロック
の温度分布が不均一になるので，予備加熱は可及的に高 い温度で行った方が良いと報告している．また，万う着 に関する研究の報告の多く4,5,11,16,26,27) はその根执 は不 明だが，予備加熱温度は $600^{\circ} \mathrm{C}$ 付近で行っている.

第 2 報24) で得た結果 (図 15) では，4 種埋没材ともそ の熱膨張率は $600^{\circ} \mathrm{C}$ 付近で一定となり，埋没ブロックが 最も安定し, 前述の操作 $1(0)$, 操作 2(150), 操作 3 （300）とは異なり， 万う着温度までのいくつかの変 態点をすでに通過してしまい安定状態になっている。

以上のことより，埋没ブロックの熱膨張率が安定期に あるということで，操作 4（600）を設定した.

\section{2. 実験結果について}

1）支台装置の三次元的変位について

A）移動

ろう着による支台装置の三次元的変位を，各次元ごと の直線的な移動について調べた.

$\Delta \mathrm{X}$ (近遠心的移動量) では，今回設定した水準内で最 も大きな熱膨張率を示す Deg が，予備加熱操作を違え ても移動量の変化は小さく，比較的一定した小さな值を 示した. また Sa では操作 1 （0）と操作 4（600）が 操作 2（150）と操作 3（300）に比べ大きな移動量を, $\mathrm{CM}$ では操作 1 (0), 操作 2 (150) および操作 3 (300) において小さな移動量を示したのに対し操作 4 (600) で 大きな移動量を, $\mathrm{R} \& \mathrm{R}$ では操作 3 (300) と操作 4 (600) が操作 1 （0）と操作 2（150）に比べ大きな移 動量を示す傾向が認められ，予備加熱操作の違いにより 移動量が変化した.

移動方向は, Deg を除く他の 3 種埋没材で, ほとんど の試験体の支台装置がポンティック側へ移動し，ブリッ ジ全体として近遠心的長さが減少する傾 向が認められ た. この原因としては，野口息の報告のとおり，ろうの 凝固収縮によるものと考えられ，それに埋没材の熱膨張 率の大きさが特に影響したのではないかと推察される.

ろう着によるブリッジ全体としての近遠心的長さの変 化については，多くの研究報告4,12,13,33,37,53)があり，そ の中でも今回の研究報告同様, 直線型のブリッジを想定 し, 埋没材の熱膨張率の大きさといら観点から考察した ものには, Hollenback ら ${ }^{12)}$, Pazzini ら ${ }^{331}$ の報告がある. これらはいずれも，600〜 $700^{\circ} \mathrm{C}$ で 0.7〜 0.8\%の熟膨張 率を示すものが最も小さな変化を示し，それより熱膨張 率が小さいと近遠心的長さが減少し, 逆に大きいと長さ が増加すると述べられている. 今回著者が得た結果で も，ろう着温度 $760 \sim 850^{\circ} \mathrm{C}$ で $0.80 \sim 0.83 \%$ の熱膨張 
率を示す Deg が予備加熱操作を違えても，近遠心的長 さの変化は小さく一定しており，Hollenback ら ${ }^{12)}$, Pazzini ら ${ }^{33)}$ の報告と一致した.

また操作 4 （600）では，ほぼ熱膨張率の大きさとは 逆に，すなわち Deg, Sa, CM, R \& R の順に移動量が大 きくなる傾向が認められた，これは，操作 4 (600) では 埋没材が最も膨張した状態で, かつろう着適応温度籁 囲 ${ }^{24)}$ に入り，埋没ブロックが安定した状態となるため, 埋没材の熱膨張率の差により生じたものと考えられる.

今回の計測の結果から移動量がいくら0に近くても優 れた埋没材，優れた予備加熱操作とは評佃できないと考 え，移動量のばらつきについても検討を加えた，その結 果, Deg は小さなばらつきを示したが， $\mathrm{CM}$ と R \& R で は大きなばらつきを示すむのが認められた，すなわち， 熱膨張率の大きな埋没材の方が小さなばらつきを示寸傾 向が認められた.

$\Delta \mathrm{Y}$ (頖舌的移動量) では，埋没材および予備加熱操作 の違いによる移動量の変化はほ上んどなく，移動量の平 均值およびばらつきも小となった．またほとんどの試験 体は，支台装置が若干ではあるが煩側へ移動する傾向が 認められた。

$\Delta Z$ (垂直的移動量) でも，埋没材および予備加熱操作 の違いによる移動量の変化は小さく，ほとんどの試験体 の支台装置が歯頸部側へ移動する傾向が認められた，そ して, Deg, Sa，CM では操作 1 (0) が操作 2 (150),

操作 3（300）抢よび操作 4（600）に比べ咬合面側へ移 動する， R \& R では操作 3（300）と操作 4 （600）が操 作 1 （0）と操作 $2 （ 150 ）$ に比へ咬合面側へ移動する 傾向が認められた.

以上のように，ろう着によりほとんどの試験体の支台 装置が，ポンティック側へ移動すると同時に，煩側へか つ歯頸部側へ移動する傾向が認められ，その移動量は埋 没材および予備加熱操作の違いにより变化した，そし て, その変化の度合は, $\Delta \mathrm{X}$ (近遠心的移動量) で最も大 となり, $\Delta \mathrm{Z}$ (垂直的移動量), $\Delta \mathrm{Y}$ (煩舌的移動量) の順に 小となる傾向が認められた.この原因としては，万ら着 部をポンティック両側隣接面に, 継ぎ手の形状7 10)を 笑き合わせに設定しているため，万うの凝固による影響 を直接受けること，また今回のような目画部の直線型の ブリッジでは，埋没ブロックの近遠心幅が高さおよび煩 舌幅に比べ長くなり, 熱膨張率の大きさの違いによる影 響を受けやすいことが考えられる.

B）対じれ

ろう着による支台装置の三次元的変位を，前述の直線
的な移動に加え，座標軸の回転により示したねじれにつ いても検討した。

ねじれは，支台装置上の 3 計測点の各次元ごとの直線 的な移動量の差により変化し，その差が大きければ，㸚 じれの角度も大きくなる. そして， $\Delta \theta \mathrm{X}$ および $\Delta \theta \mathrm{Y}$ は, 特に Z座標における移動量の差に影響を受け，理解しや すいよう臨床的な表現にかえると， $\Delta \theta \mathrm{X}$ は支台装置が隣 接面観でどのように㸚じれ，傾斜したかを， $\Delta \theta \mathrm{Y}$ は支台 装置が煩側または舌側面観でどのようにねじれ，傾斜し たかを表す。また， $\Delta \theta Z$ は特にXおよびY座標における 移動量の差により影響在受け，支台装置が咬合面観でど のようにねじれ，回転したかを表す。

埋没材抢よび予備加熱操作の違いによる, 回転角度の 変化は小さく，ほとんどの試験体の支台装置が，舌側よ りも煩側が，ポンティック側よりも反ポンティック側が それぞれ下に位置する㸚じれを示し，ワーピースキャス 卜法で問題となる孤状変形3) とは逆のねじれを示寸傾向 が認められた。また咬合面観では，5恃計回りに，77 は反時計回りに回転する傾向が認められた。 そして，以 上のような傾向は, 特に操作 1 (0), 操作 2 (150) 抢 よび操作 3 (300) で認められた。 この原因として, 予 備加熱なしの操作 1 (0), 予備加熱温度の低い 操作 2 （150）と操作 3（300）においては，万弓着前にろう着 可能な状態，すなわち被ろう着体に加えた熱が埋没材に 奪われなくなる状態まで，埋没ブロック全体を火炎に て，あらかじめ加熱し，万う着操作に移行したが，万う 着時に集中的に火炎があたる埋没ブロックの中央部と端 の方との間，また上部と基底部との間の温度分布に差が 生じたと考えられる，すなわち，埋没ブロックの上部の 中央部でろう着温度 $\left(760 \sim 850^{\circ} \mathrm{C}\right)$ 付近に達していたの に対し，端の方および基底部ではその温度に達していな かったため，熱膨張が追いつかず（図 15 参照），埋没つ ロックが複雑に変形し，权じれが生じたと推察される。

これに対し，万う着前の火炎による埋没ブロックの加熱 を必要とせず，すぐにろう着操作に移行できる操作 4 (600)では，埋没材が最も熱膨張した状態で，加ろう 着適応温度範囲 ${ }^{24)}$ に入るため, $600^{\circ} \mathrm{C}$ 以上で埋没ブロッ クの温度分布に差が生じても，図 15 に示すような埋 没 材は一定した熱膨張率を示すため，7の $\Delta \theta \mathrm{X}$ を除き， 操作 1 (0), 操作 2（150）㧍よび操作 3（300）のよう な傾向がほとんど認められなかったのではないかと推察 される。

また， $\mathrm{CM}$ と R \& R では大きなばらつきを示すもの が認められ, $\Delta \mathrm{X}$ (近遠心的移動量) 同様, 熱膨張率の大 
きな埋没材を使用した方が小さなばらつきを示す傾向が 認められた。

2） 2 要因の影響について

前述までの直線的な移動および座標軸の回転により示 した权じれのみでは, 埋没材と予備加熱法の 2 要因が適 合精度にどのような影響を及ぼすのか，臨床的に理解す ることは困難である。 そこで Nicholls ら ${ }^{17,22)}$ と同様に, $\Delta \mathrm{X}$ (近遠心的移動量), $\Delta \mathrm{Y}$ (煩舌的移動量) および $\Delta Z$ (垂直的移動量)よりベクトルの内積 $\left(\sqrt{\Delta \mathrm{X}^{2}+\Delta \mathrm{Y}^{2}+\Delta \mathrm{Z}^{2}}\right)$ を行い，ベクトルの長さ，すなわち三次元空間における

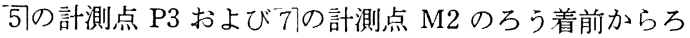

表 5 ベクトル值 $\left(\sqrt{\mathrm{X}^{2}+\Delta \mathrm{Y}^{2}+\Delta \mathrm{Z}^{2}}\right)$

\begin{tabular}{|c|c|c|c|c|c|}
\hline & & Deg & $\mathrm{Sa}$ & $\mathrm{CM}$ & $\mathrm{R} \& \mathrm{R}$ \\
\hline \multirow{5}{*}{5} & 0 & $\begin{array}{l}0.021 \\
(0.006)\end{array}$ & $\begin{array}{c}0.032 \\
(0.013)\end{array}$ & $\begin{array}{c}0.024 \\
(0.013)\end{array}$ & $\begin{array}{c}0.028 \\
(0.013)\end{array}$ \\
\hline & 150 & $\begin{array}{c}0.018 \\
(0.006)\end{array}$ & $\begin{array}{c}0.019 \\
(0.011)\end{array}$ & $\begin{array}{c}0.020 \\
(0.006)\end{array}$ & $\begin{array}{c}0.027 \\
(0.011)\end{array}$ \\
\hline & 300 & $\begin{array}{l}0.021 \\
(0.017)\end{array}$ & $\begin{array}{l}0.017 \\
(0.003)\end{array}$ & $\begin{array}{l}0.040 \\
(0.004)\end{array}$ & $\begin{array}{l}0.057 \\
(0.035)\end{array}$ \\
\hline & 600 & $\begin{array}{c}0.020 \\
(0.010)\end{array}$ & $\begin{array}{c}0.027 \\
(0.007)\end{array}$ & $\begin{array}{c}0.033 \\
(0.012)\end{array}$ & $\begin{array}{c}0.059 \\
(0.026)\end{array}$ \\
\hline & & Deg & $\mathrm{Sa}$ & $\mathrm{CM}$ & $\mathrm{R} \& \mathrm{R}$ \\
\hline \multirow{4}{*}{7} & 0 & $\begin{array}{c}0.023 \\
(0.005)\end{array}$ & $\begin{array}{c}0.053 \\
(0.019)\end{array}$ & $\begin{array}{c}0.038 \\
(0.011)\end{array}$ & $\begin{array}{c}0.024 \\
(0.008)\end{array}$ \\
\hline & 150 & $\begin{array}{c}0.022 \\
(0.007)\end{array}$ & $\begin{array}{c}0.031 \\
(0.017)\end{array}$ & $\begin{array}{c}0.031 \\
(0.018)\end{array}$ & $\begin{array}{c}0.031 \\
(0.013)\end{array}$ \\
\hline & 300 & $\begin{array}{c}0.017 \\
(0.007)\end{array}$ & $\begin{array}{c}0.026 \\
(0.010)\end{array}$ & $\begin{array}{c}0.050 \\
(0.035)\end{array}$ & $\begin{array}{c}0.050 \\
(0.017)\end{array}$ \\
\hline & 600 & $\begin{array}{c}0.017 \\
(0.007)\end{array}$ & $\begin{array}{c}0.043 \\
(0.011)\end{array}$ & $\begin{array}{c}0.047 \\
(0.012)\end{array}$ & $\begin{array}{c}0.070 \\
(0.017)\end{array}$ \\
\hline
\end{tabular}

単位: $\mathrm{mm}():$ S. D.
う着後までの移動方向の要素を含まない移動量（以下べ クトル值と略す）より，種々の統計処理を行い，総合的 な評価を行った，その結果を表 5〜10, 図 16〜19 に示 す.

表 6 は, 埋没材 (A), 予備加熱法 (B) の 2 要因を設定 し，二元配置分散分析を行ったものである.これによる と，可・7〕ともに埋没材が危険率 $1 \%$ で，予備加熱法が 危険率 5\% で有意となり，埋没材と予備加熱法の交互作 用では，57で危険率 5\% で，77で危険率 1\% で有意とな り，すべての要因が適合精度に影響を及ぼすことが判明 した. また，その奇与率は予備加熱法，埋没材と予備加 熱法の交互作用，埋没材の順に大となり，この順に適合 精度に及ぼす影響が大となることが判明した。

そこで，適合精度に及ぼす影響が最も大となった埋没

表 6 埋没材と予備加熱法とがベクトル值に及ぼす影響の分 散分析表

\begin{tabular}{|c|c|c|c|c|c|c|}
\hline & 要因 & S. S. & D. F. & M. S. & F. & $\rho(\%)$ \\
\hline & A & 0.0058 & 3 & 0.0019 & $9.45^{* *}$ & 20.2 \\
\hline & B & 0.0025 & 3 & 0.0008 & $4.05^{*}$ & 7.3 \\
\hline \multirow[t]{6}{*}{5} & $A \times B$ & 0.0040 & 9 & 0.0004 & $2.18^{*}$ & 8.4 \\
\hline & e & 0.0132 & 64 & 0.0002 & & \\
\hline & $\mathrm{T}$ & 0.0256 & 79 & & & \\
\hline & 要因 & S. S. & D. F. & M. S. & F. & $\rho(\%)$ \\
\hline & A & 0.0072 & 3 & 0.0024 & $10.55^{* *}$ & 20.7 \\
\hline & B & 0.0023 & 3 & 0.0007 & $3.46^{*}$ & 5.0 \\
\hline \multirow[t]{3}{*}{7} & $\mathrm{~A} \times \mathrm{B}$ & 0.0074 & 9 & 0.0008 & $3.62^{* *}$ & 16.7 \\
\hline & e & 0.0147 & 64 & 0.0002 & & \\
\hline & $\mathrm{T}$ & 0.0319 & 79 & & & \\
\hline
\end{tabular}

注) S. S.: 平方和 D. F.: 自由度 M. S. : 平均平方和 $\mathrm{F}$. : 分散比 $\rho$ : 奇与率 $\mathrm{A}$ : 埋没材 $\mathrm{B}$ : 李備加熟法 $\mathrm{e}$ : 残差 $\mathrm{T}$ : 給計 $* *$ : 危険率 $1 \%$ で有意 ・:危険率 $5 \%$ で有意

表 7 一埋没材がベクトル值に及ぼす影旡の分散分析表

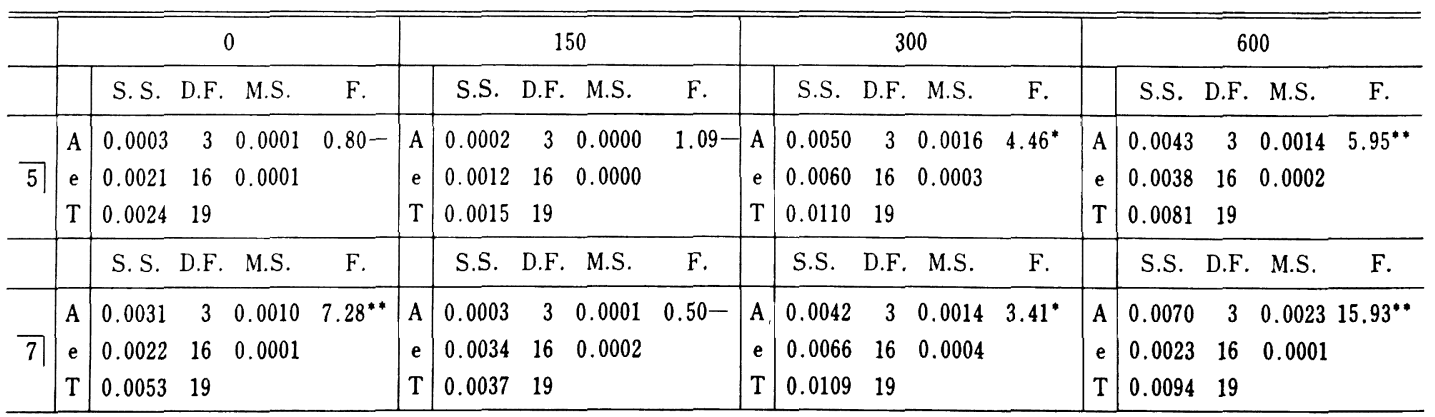

注) S.S.: 平方和 D.F.：自由度 M.S.：平均平方和 F.: 分散比 A：埋没材 e：残差 $\mathrm{T}:$ 総計 ${ }^{* *}$ : 危険率 $1 \%$ で有意 *: 危険率 $5 \%$ で有意 
材が， 4 種予備加熱操作個々にどのような影響を及ぼし ているのかを調べるため, 埋没材 (A) の 1 要因を設定 し，一元配置分散分析を行ったものが表 7 である. これ によると，5・7ともに操作 3 （300）では危険率 5\% で, 操作 4 （600）では危険率 1\% で有意となり, 操 作 1（0）では先にろう着した5では有意とならなかった が, 後でろう着した7てで危険率 $1 \%$ で有意となり, 埋没 材の違いによる影響が認められた.

4 種埋没材のベクトル值を各予備加熱操作ごとにみた のが図 16,17 であり，埋没材間の T-検定による比較(表 8）とを合わせて考察すると, 予備加熱操作が変化して もDeg が他の 3 種埋没材に比べ一定した小さな值を示 し良好な適合精度が得られた，また，特に操作 4 （600） において, Deg, Sa, CM, R \& R の順に，すなわち熱膨

表 8 ベクトル値のT-検定（埋没材間の比較）

\begin{tabular}{|c|c|c|c|c|c|}
\hline & 対 応 & 0 & 150 & 300 & 600 \\
\hline \multirow{7}{*}{5} & $\mathrm{Deg}-\mathrm{Sa}$ & - & - & - & - \\
\hline & $\mathrm{Deg}-\mathrm{CM}$ & - & - & - & - \\
\hline & Deg-R \& R & - & - & - & * \\
\hline & $\mathrm{Sa}-\mathrm{CM}$ & - & - & $* *$ & - \\
\hline & $\mathrm{Sa}-\mathrm{R} \& \mathrm{R}$ & - & - & - & * \\
\hline & $\mathrm{CM}-\mathrm{R} \& \mathrm{R}$ & - & - & - & - \\
\hline & 対 応 & 0 & 150 & 300 & 600 \\
\hline \multirow{6}{*}{7} & $\mathrm{Deg}-\mathrm{Sa}$ & • & - & - & $* *$ \\
\hline & $\mathrm{Deg}-\mathrm{CM}$ & $*$ & - & - & $*$ \\
\hline & Deg-R \& R & - & - & $* *$ & $* *$ \\
\hline & $\mathrm{Sa}-\mathrm{CM}$ & - & - & - & 一 \\
\hline & $\mathrm{Sa}-\mathrm{R} \& \mathrm{R}$ & * & - & $*$ & * \\
\hline & $\mathrm{CM}-\mathrm{R} \& \mathrm{R}$ & * & - & - & * \\
\hline
\end{tabular}

注）一：有意差なし（色険率 $5 \%$ ）

・ : 有意差あり（危険率 $5 \%$ )

*・: 有意差あり（危険率 $1 \%$ ）
張率の大きさと逆（図 15）に大きな移動量を示す傾向が 認められた. この原因としては, 操作 4（600）では埋 没材が最も熱膨張し，かつろう着適応温度籁囲 ${ }^{24)}$ に入り 安定した状態となるため, 埋没材の熱膨張率の差が明確 に表れたと考えられる.

予備加熱操作の違いが 4 種埋没材個々にどのような影 響を及ぼしているかを調べるため, 予備加熱法（B）の 1 要因を設定し，一元配置分散分析を行ったものが表 9 である.これによると, Deg では5・7ともに有意とな らす，予備加熱操作の違いによる影響がないと推察され る. Sa と R \& R では後にろう着した7で, それでれ危 険率 $5 \%$ と $1 \%$ とで有意に，CM では先にろう着したら で危険率 5\% で有意となり，予䚚加熱操作の違いによる 影響が認められた。

表 10 ベクトル值のT-検定（予㘃加熱操作間の比較）

\begin{tabular}{rc|c|c|c|c}
\hline & 対 応 & Deg & Sa & CM & R \& R \\
\hline $0-150$ & - & - & - & - \\
$0-300$ & - & $*$ & $*$ & - \\
$0-600$ & - & - & - & $*$ \\
\hline 5 & $-150-300$ & - & - & $*$ & - \\
$150-600$ & - & - & - & $*$ \\
$300-600$ & - & $*$ & - & - \\
\hline & 对 応 & Deg & Sa & CM & R \& R \\
\hline $0-150$ & - & - & - & - \\
$0-300$ & - & $*$ & - & $*$ \\
$0-600$ & - & - & - & $*$ \\
\hline 7 & $150-300$ & - & - & - & - \\
$150-600$ & - & - & - & $*$ \\
$300-600$ & - & $*$ & - & - \\
\hline
\end{tabular}

注）一：有意差なし（危除率 $5 \%$ ）

・：有意差あり(危険率 $5 \%$ )

* : 有意差あり（危険计 $1 \%$ ）

表 9 予備加熱法がベクトル值に及ぼす影響の分散分析表

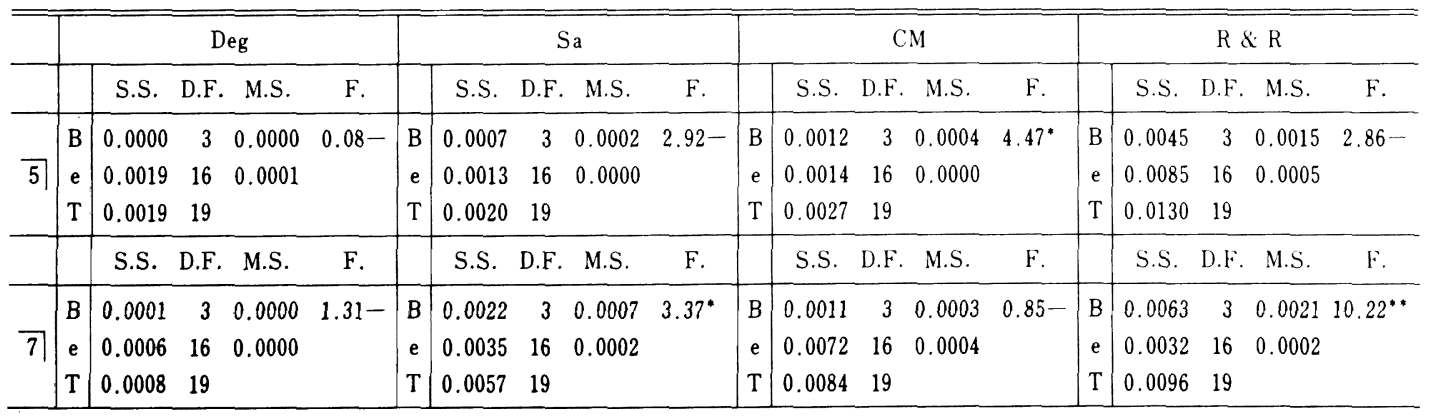

注) S.S.: 平方和 D.F.: 自由度 M.S. : 平均平方和 F.: 分散比 B：孙備加熱法 $\mathrm{e}$ : 残差 $\mathrm{T}$ : 紷計 **：危険率 $1 \%$ で有意 *：危険率 $5 \%$ で有意 


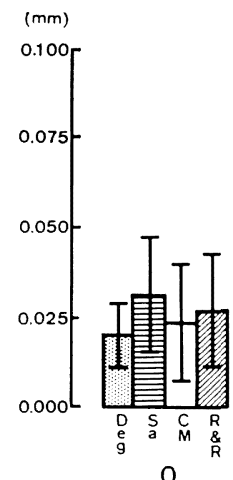

0

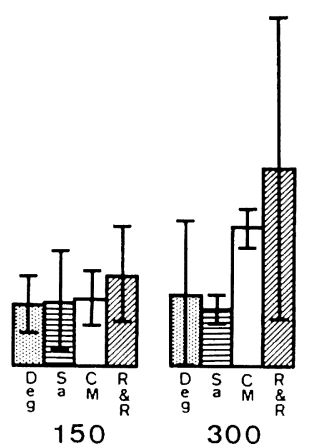

図 16 可・・゙クトル値

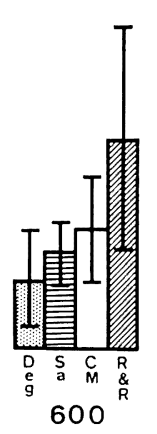

600

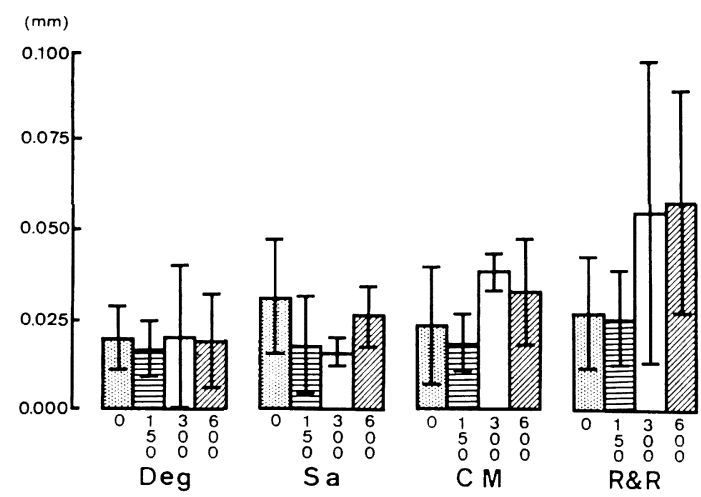

図 $18 \overline{5}$ ・・ベクトル值

4 種予備加熱操作のベクトル值を各埋没材ごとにみた のが図 18, 19 であり，予備加熱操作間の T-検定による 比較（表 10）と合わせて考察すると，4種埋没材に共通 して良好となる予備加熱操作は認められなかったが, Deg は特に各操作間に差は認められなかった. CM では 5.77とも，操作 1（0）と操作 2（150）との間に危険 率 5\%で有意差が認められず，このことよりメーカーが 予備加熱を特にする必要がないと表示しているのではな いかと推察する.

被万う着体金属の酸化膜の形成を肉眼的に観察する と，操作 3 (300) ではその金属色は消失しなかったが, 操作 4 (600) では黒変し酸化膜の形成が認められた. こ のことより著者も湯田 ${ }^{28,39)}$ の報告同様, 予備加熱温度は $300^{\circ} \mathrm{C}$ にとどめるべきだと考える.

火炎ろう着では, どうしても埋没ブロックの温度分布 に差が生じやすいので, 可及的に差が生じないような改 善策をみつけ出す必要があると考える. その 1 つの改善 策として現段階では，埋没ブロックを可及的に小さくす

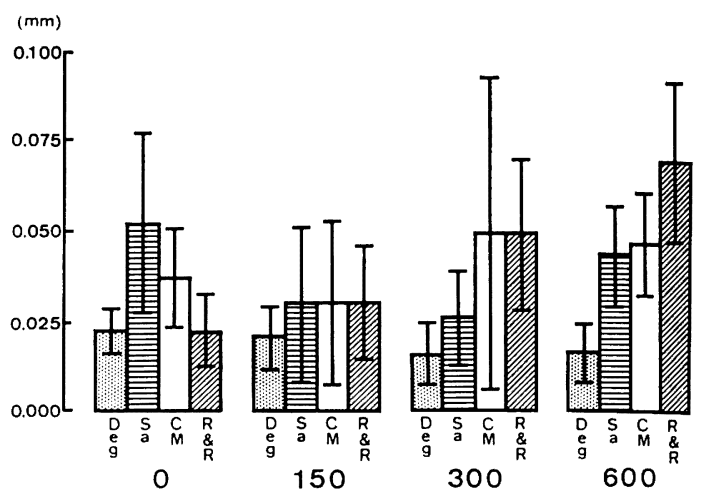

図 17 7 1 ・・゙クトル值

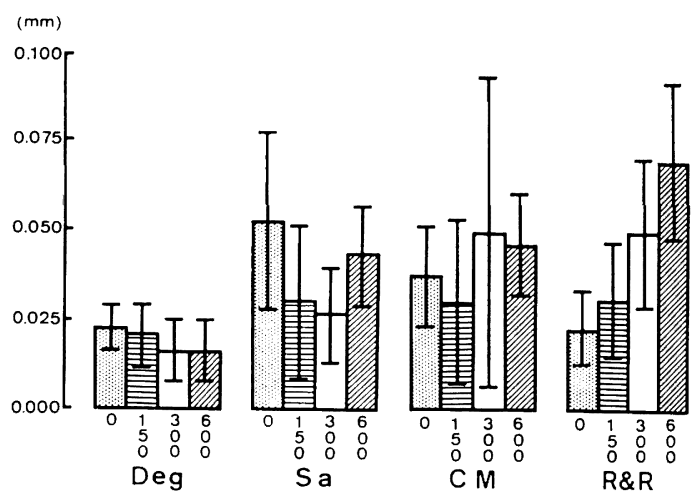

図 $19 \overline{7} \mid \cdot$ ベクトル值

ること, 乾燥性, 熱伝導性が良く, 可及的に低い温度で ろら着適応温度となる埋没材の改良等が考えられるの で，これらの点に関しても追求すべきであろう.

以上を総括すると, 今回取り上げた 2 要因の組合わせ の中で最もべクトル值の小さかった埋没材は Deg で, 予備加熱操作は操作 2 （150）であった.

\section{第 6 章 結 論}

ろう着時の埋没材および予備加熱法の 2 要因が, 適合 精度に及ぼす影響を解明する目的で， 6次損で5・7〕を 全部鋳造冠支台装置とするスリーユニットブリッジのろ う着時による両支台装置の三次元的変位を計測し，移動 量, ねじれとベクトル值でそれぞれ検討したところ以下 の結論を得た.

1) 㨁線的な移動とねじれでは, 埋没材および予備加 熱法の違いによる影響が特に近遠心的移動量 $(\Delta \mathrm{X})$ で大 となった。 
2）埋没材と予備加熱法とが適合精度に及ぼす影響 は, 予備加熱法, 埋没材と予備加熱法との交互作用, 埋 没材の順に大となった.

3）万う着時の埋没材のうち, 最も熱膨張率の大きい Deguvest L (Degussa 社) を用いると，予備加熱法のい かんを問わず良好な適合精度が得られた.

4）、ずれの埋没材でも，予備加熱は $150^{\circ} \mathrm{C}$ で行う ことが，良好な適合精度を得るため重要であることが判 明した.

稿を終わるにあたり，本研究に際し始終ご愁篤なるご指尊ご 校閱を賜りました日本大学五十嵐孝義教授ならびに中澤 靖教 授，またご専攻の立場からご指導を睗りました日本大学大橋正 敬教授, 大木一三教授, 森谷良彦教授に深く感謝の意を表しま す.

あわせて, 日頃ご助嵱ご鞭撻を頂きました補緅第 3 講座医局 員各位, 大学院生各位に対し感謝の意を表します。

なお，本研究の一部は日本大学歯学部佐藤研究費によった。

\section{Summary}

In the clinical practices of the Crown and Bridge Prosthetics, the developments and improvements achieved in the instruments have made the adoption of the indirect method a day-to-day affair and have enabled the making of fixed restorations with adequate accuracy. It has now become possible to easily make a bridge for the portion where 1 or 2 teeth are missing with the one-piece cast technique and this technique is now beginning to be applied also to the making of a bridge for the portion where 3 or more teeth are missing. However, in the cases where there are restrictions due to the abutment tooth contour or where there are many units, the assembly operation is done, even today when the indirect method is already well established, with the soldering method which is employed in parallel with the checking of fitness accuracy. Also, as in the cases where different kinds of metals are joined together or where the prosthetic techniques are employed using attachments or telescope system, there are many instances in which the reliance on the soldering method is either absolutely necessary or its adoption is preferable.

This soldering method not only uses many kinds of materials and requires complex assembling process but also necessitates a high level of technique. Hence, there are many factors that affect the fitness accuracy of the bridge assembled with the soldering method. For this reason, many a study has been made on the soldering method itself but, so far, we can hardly say as yet that a systematic soldering method has been established.

So, the author has taken up, from among the various factors that affect the fitness accuracy of the soldering method, the following two factors, viz., (1) soldering investment and (2) preheating procedure, and, with the purpose of clarifying the effects that these two factors give to the fitness accuracy, measured the three dimensional distortions of the retainers. Following are the conclusions obtained as a result of the measurements and examinatios done by the author:

1. With respect to the linear distortion and rotational distortion, the effects resulting from the differences in the types of soldering investments and the preheating procedures used were particularly large in terms of the volume of mesiodistal distortion ( $\mathrm{A} \mathrm{X})$.

2. As to the effects given to the fitness accuracy by the soldering investment and the preheating procedure used, the largest effect was given by the soldering investment, which was followed in the intensity of effects by the interacation of soldering investment and preheating procedure, and then by the preheating procedure.

3. It was found that, among the various kinds of soldering investments used at the time of the soldering, the Deguvest L (manufactured by the Degussa, Inc.) with the highest thermal expansion ratio produced good fitness accuracy regardless of the type of the preheating procedures used.

4. It was found that, regardless of the type of the soldering investments used, the preheating at the temperature of $150^{\circ} \mathrm{C}$ was a most important factor in obtaining good fitness accuracy.

\section{文献}

1）晹田雅士：歯科技工に拈ける錤付について一第８回一, 歯科技工, $8: 65 \sim 73,1979$.

2）真坂信夫，斎藤信義：ブリッジはワンピース・キャスト 法で何本までできま寸か，齿科技工，2：160 164， 1974.

3）金竹哲也, 中村健吾, 真坂信夫, 高橋重雄: 座锬会 鉱 造体の適合精度について (上), DE, $36: 1 \sim 13,1976$.

4）西村文夫, 山口重雄, 和久本貞雄: 各種鉬付法㧍上び一 塊䤲造による橋義歯の精度について, 蒾材器誌, $6: 41$ 46, 1961.

5） Tylman, S.D. : ティルマン クラウンブリッジ (下), 714 737, 医迷薬出版, 東京, 1974. 
6）水島 涁：鑞着法でブリッジを製作する祭，その適合精 度に影響寸る因子について，歯科技工，3:39 43， 1975.

7）歯科理工学会編：菌科理工学, 141 148, 医蒌薬出版, 東京, 1971 .

8）湯田雅士：歯科技工における鑞付について一第 9 回一, 婵科技工, $7: 148 \sim 158,1979$.

9）アメリカ溶接協会編：万う付マニュアル，79 107, 工 学図書, 東京, 1980 .

10）日本溶接協会編：万うの選び少・使い方，87 104, 座 報出版, 東京, 1981 .

11) Ryge, G. : Dental soldering procedures, Dent. Clin. N. Amer., $11: 747 \sim 757,1958$.

12) Hollenback, G.M. \& Shell, J.S. : The accuracy of dental appliances assembled soldering, J. Cali. state dent. Ass., $41: 207 \sim 210,1965$.

13) Stackhouse, J.A. : Assembly of dental units by soldering, J. Prosth. Dent., $18: 131 \sim 139,1967$.

14）保母須弥也：オーラルリハビリテイション，516～525, $742 \sim 749$, 医蒾薬出版, 1968 .

15) Skinner, E.W. \& Phillips, R.W.：スキンナー歯科材 料学 (下), 468 485, 医画菜出版, 東京, 1970 .

16）Jelenko, J.F. \& Co, Inc：最新版クラウンブリッジの 製作法, 89 122, 医歯薬出版, 東京, 1978 ,

17) Willis, L.M. \& Nicholls, J.I. : Distortion in dental soldering as affected by gap distance, J. Prosth. Dent., $43: 272 \sim 278,1980$

18）野口八九重：ろう付け法とワンピースキャスト法一中間 支台齿を持つブリッジを手がかりに一，日本歯科評碖， $477: 97 \sim 109,1982$

19）野口八九重：齿科における接合技術, 金属, 50:21 28,1980 .

20）湯田雅士：歯科技工における鑞付について一第 19 回一, 歯科技工，9:555 571，1981.

21）湯田雅士：歯科技工に执ける鐶付について一第 12 回一, 歯科技工, $7: 563 \sim 577,1979$.

22) Harper, R.J. \& Nicholls, J.I. : Distortion in indexing methods and investing media for soldering and remount procedures, J. Prosth. Dent., $42: 172 \sim 179$, 1979.

23）高橋敏政：マグネシア采埋没桄による真空ろう付けに閔 寸る研究, 歯材器誌, $37: 1 \sim 12,1980$.

24）富四 豊, 羽田京太郎, 石冢 享, 小泉政幸, 長島信也, 栈 淑行, 庄司喜則, 横倉正典, 中沢 清, 牟田 成, 五十嵐孝義：米科万う着に関する研究 第 2 報 万う着 尃用埋没材の理工学的性 質, 補緅 誌, $27: 823 \sim 832$, 1983.

25）津江明伸, 富田 豊, 羽田京太郎, 行田克則, 守 屋義
雄，小泉政幸，中沢 清，東風 巧，大島修一，五十嵐 孝義：歯科ろう着に関する研究 第 3 報 リン酸塩系埋 没材の理工学的性質, 補綴誌, $27: 1254 \sim 1261 ， 1983$.

26) 松葉 久: 鑞接用埋没材の研究, 歯材器誌, $3: 47 \sim 59$, 1959.

27）野本 直, 西村文夫, 山口重雄 : ろう付け用埋没材とそ の使用条件, 歯材器誌, $6: 82 \sim 90,1961$.

28）湯田雅士：鑞付用埋没材の研究 第 1 報 主として市販 鑞付用埋没材の硬化膨張，圧縮強度，重量変化および加 熱膨張について, 日本歯科技工士学会誌, $95 \sim 108$, 1977.

29）湯田雅士：鏁付用埋没材の研究 第 2 報 被鏁付体埋没 時に及ぼす埋没材の加熱膨張について，日本歯科技工士 学会誌, 109 112, 1977.

30）川崎従道 : 私のテレスコープ義歯製作法一特にミルド・ バーのパターン製作と鎿着操作を中心として一，歯科技 工, $5: 1 \sim 24,1977$.

31）小㶯津純男：大型補緅物の鑞着法についてーアルゴン雲 囲気炉内鑞着法抢よび被錙着体金属固定装置について一 歯科技工, $6: 219 \sim 229,1978$.

32）丹羽正勝：万うつけ專用埋没材の試作に関寸る研究一主 として埋没材の組成と寸法変化およびろうゔけ間隙との 関係について一，歯材器誌，36:187 201, 1979.

33) Pazzini, N.A., Pazzini, L.I., Araujo, P.A. \& Lopes, E.A. : The accuracy of soldering investment, J. Prosth. Dent., 42 : 530 533, 1979.

34） Gaerny, A. : C.I.S. システムによるテレスコープ義歯, $66 \sim 68,103$, 医歯薬出版, 東京, 1979.

35）野本吉輝：改良型電気溶接器を使用した仮着および錙着 について，歯科技工， 8:401 411，1980.

36）妹尾輝明，植野正人：考案したセラミック製被錙着体固 定装置を用いた陶材焼付ブリッジの炬内錙着, 歯科技 工, $9: 233 \sim 238,1981$.

37）羽田京太郎, 富田 豊, 小泉政幸, 石塚 享, 長島信 也, 栈 淑行, 车田 成, 八木帇行, 浅野澄明, 五十嵐 孝義，歯科乃う着に関する研究 第 1 報 埋没材の種類 による影響，補緅誌，26：900～909，1982。

38）太田晶次, 三宅宗次, 篠崎照泰, 木下浩志, 西田彰宏, 玉瞋敏夫：陶材焼付冠の後万う着時における被ろう着体 固定装置の一考察，日本歯科技工士学会誌， $4: 32 \sim 35$, 1983.

39）湯田雅上：歯科技工における蠟付について一第 4 回一, 歯科技工, $6: 258 \sim 271$, 1978.

40）羽田京太郎, 富田 豊, 守屋義雄, 津江明伸, 行田克則, 高橋章浩, 中沢 清, 東風 巧, 大島修一, 牟田成, 五十嵐孝義：歯科万う着に関する研 究 (第 4 報), 補緅 誌, $27: 943 \sim 956,1983$.

41）湯田雅士：歯科技工における蠟付について一第 5 回一, 
歯科技工， $6: 321 \sim 330,1978$.

42）湯田雅士 : 連結部の問題点一特に蠟付操作上の注意点一, 補敍臨床別冊 ブリッジの臨床, : 211 224, 1982.

43）御崎勝雄: 金属焼付ポーセレンにおける私の後鋃着法一 1. 3. 6. 8. 法について一, 歯科技工, $3: 11 \sim 18$, 1975.

44）市丸俊夫, 㞮田 務: 歯科用高周波口ウ付法について, 歯理工誌, $18: 93 \sim 102,1977$.

45）野口八九重：レーザー溶接はろう付に代わりうるか, 金 属, $48: 18 \sim 21,1978$.

46）湯田雅士：歯科技工における蠟付について一第 13 回一, 歯科技工, $8: 155 \sim 167,1980$.

47）湯田雅士：歯科技工における侅付について一第 14 回一, 歯科技工, $8: 413 \sim 426,1980$.

48）湯田雅士：歯科技工における蚊付について一第 15 回一, 歯科技工, $8: 523 \sim 542,1980$.
49) Nicholls, J.I. : The measurement of distortion, Theoretical considerations, J. Prosth. Dent., 38 : 578 586, 1977.

50) Nicholls, J.I. : The measurement of distortion, Mathematical considerations, J. Prosth. Dent., 39 : $339 \sim 343,1978$.

51) Nicholls, J.I. : The measurement of distortion, Concluding remarks, J. Prosth. Dent., $43: 218 \sim$ 223, 1980.

52）大野弘機：歯科用貴金属合金の高温酸化に関寸る研究 第 1 報 酸化層の形成と酸化速度, 歯理工誌, $17: 297$ $312,1976$.

53）細田裕康, 三上慧一郎, 鶴貝隆男, 神田正一: 橋義歯の 適合精度判定のための新しい評価法, 歯材器誌, 34 : $233 \sim 241,1977$. 